\title{
Research on Factors Affecting to Customers' Intention to Online Shopping: Empirical Evidence in Vietnam Emerging Economy
}

\author{
TOAN DUC LE, PHU HUU NGUYEN \\ Graduate School of Duy Tan University \\ 182 Nguyen Van Linh Street, Danang City, VIETNAM \\ TAM QUANG NGUYEN, THUYÊN NGOC NGUYEN \\ Duy Tan University \\ 182 Nguyen Van Linh Street, Danang City, VIETNAM \\ MAN QUANG LE \\ Faculty of Accounting \\ University of Finance - Marketing, Ho Chi Minh City, VIETNAM
}

\begin{abstract}
The aim of study is to research the factors affecting customers' intention to online shopping in Vietnam emerging economy. The study integrates TAM and TPB in that it added the reliability- law factor as a formative factor. The study's results demonstrate that reliability -law factor greatly affects to the online shoppers' behavioral intention. The study's results indicate that the proposed model is applicable to measure the intention for online shopping of consumers in Vietnam, and finally it is concluded in this research that extending TPB and TAM with a reliability - law factor may be useful to know online shopping behavior and the intention of Vietnam's consumers. Some recommendations are also suggested to the relevant state offices of Vietnam and the companies doing business in online shopping sector.
\end{abstract}

Key words: Online shopping, Legal corridor, Intention to online shopping, Reflective measurement model, Bootstrapping procedure, Vietnam emerging economy.

Received: September 30, 2019. Revised: April 24, 2020. Accepted: May 8, 2020. Published: May 15, 2020.

\section{Introduction}

Online shopping is a type of electronic commerce in which products and services are sold via the internet. Since the 1990s, online shopping has proliferated rapidly and its development is expected to accelerate further because consumers can shop or implement transactions 24 hours a day in anywhere. It has the advantages of greater access to information, competitive pricing, and short times in receiving the products. In Southeast Asia, online shopping has been the fastest growing sector of the internet economy and is set to reach \$23 billion in 2018 . Online shopping has 120 million consumers buying online from the top three players, Shopee, Tokopedia, and Lazada, who together now account for $70 \%$ of the market ${ }^{(1)}$. Vietnam's commerce market posted an average growth of $25 \%-30 \%$ per year in 2017-2018, with the retail market estimated at US $\$ 7.8$ billion. The number of IPv4 addresses using online shopping increased significantly from
16,896 IPv4 addresses in the year 2000 to 10 million in 2010; in October 2018, this number reached 15,951,360. Vietnam ranked 2nd in the Association of SouthEast Asian Nations (ASEAN) region, 8th in Asia, and 29th in the world ${ }^{(2)}$, and may continue to achieve breakthroughs since Vietnam's online shopping market is still in the nascent stage of development. Although there is great potential for development, Vietnam's e-commerce market developed chaotically and many obstacles still exist, which are described as follows:

- Vietnam ranked in the top 29 countries of internet users in 2018, but the number of consumer purchases online came from only $7 \%$ of Vietnamese Internet users this year ${ }^{(2)}$. Currently, about $50 \%$ of all transactions have a value of under VN $\$ 300,000$ (approximately US $\$ 13.00$ ) and $10 \%$ of purchases being over VN \$2,000,000 (approximately US \$87.00). 
-Consumers have difficulty in verifying between unlicensed sale and licensed sites, between knownorigin and counterfeit goods, because they could be bought the goods lack the expected quality. Many websites and their social-network transaction accounts have only virtual addresses, besides transactions of fake products via online shopping in Vietnam were lack of invoices; so relevance state offices have difficulties in controlling and handling commercial fraud.

- The legal corridor for the e-commerce sector remains inadequate. Prevailing regulations have been in effect for 5-15 years and are now outdated ${ }^{(3)}$, especially with respect to cross-border e-commerce.

-The lack of a legal corridor means that many ecommerce giants, such as Amazon, Shopee, Tokopedia, etc., have yet to enter Vietnam.

- Ninety percent of Vietnamese people use ATM cards to withdraw money instead of making epayments $^{(1)}$. The habit of using cash by Vietnamese consumers is also a 1 arge obstacle regarding the development of online shopping. The number of people who do not have bank accounts is quite large, and they are not frequently approached with modern payment technologies. For urban residents who are interested in paying for goods and services without cash, the most popular form of payment is by money transfer via ATMs, Internet banking, and credit cards.

Therefore, researching the factors that affect consumers' intentions to shop online is a necessary task to identify the problems in Vietnam's emerging e-commerce economy. This research was implemented to gain the following objectives: (1) to investigate the factors that affect consumers' intentions and the influence levels of the identified factors to online shopping in Vietnam, and (2) to propose some recommendations to promote shop online in Vietnam.

\section{Literature Review}

\subsection{The Technology Acceptance Model} (TAM), the Theory of Reasoned Action (TRA), and the Theory of Planned Behavior (TPB)

There were the three theoretical models about human behavior in this study, namely, TRA was presented by Ajzen and Fishbein [1] , TAM was presented by Davis [5], and TPB was presented by Ajzen [2].

The TRA includes four general concepts, namely, subjective norms, behavioral attitudes, intention to use, and actual use. The TRA states that the behavior of an individual can be predicted from their intentions, which can, in turn, be predicted from their attitudes and subjective norms. The TRA was used largely in marketing research and has been applied to explain behaviors regarding the acceptance of technology. However, the TRA is a very general theory and, as such, doesn't specify what specific beliefs are pertinent in particular situations.

The TAM model indicates how two important factors, i.e., perceived usefulness and perceived easeof-use influence an individual's decision regarding how and when to use a specified technology ([5]). This model's limitation is that it only focuses on the determinants of a customer's behavioral intention and does not help to identify how such perceptions are created or how they can lead to increased use.

Ajzen [2] suggested the TPB model which, along with the determinants of behavioral attitudes and subjective norms, includes a third element, perceived behavioral control. The TPB was suggested as an extension of the TRA and it was subsequently applied to explain different types of behavior.

\subsection{Previous research on internet banking and online shopping using TAM and TPB}

Lee and Ngoc [13] proposed the determinant of trust as an additional factor when researching Vietnamese university students' behavioral intentions to shop online. The results found out two important conclusions: (1) Trust extended the predictive utility of the TPB for the intention to using online shopping systems, and (2) trust acted as a moderating factor in the relationship between attitudes and behavioral intentions regarding online shopping habits of Vietnamese university students.

Nasri and Charfeddine [15] integrated the TAM and TPB models to include security and privacy, government support, self-efficacy and technology support, in addition to social norms, attitudes, perceived ease-of-use, perceived usefulness, perceived behavior control, and intention to use internet banking by Tunisian bank customers. The study used Structural equation modeling to investigate the correlations between the constructs. The results confirmed the applicability of the TAM 
and TPB models in predicting the intention to use internet banking by Tunisian bank customers.

Alsamydai [3] researched the use of mobile banking services in Jordan. In this study, the TAM was modified by introducing two new dimensions, quality and experience, to the five dimensions of the TAM. The results found out the positive correlations between all of the components and demonstrated a strong correlation between attitudes toward and the use of mobile banking services, in which components the strongest correlation was found between the experience and perceived ease-of-use domains.

Shergill and Chen[18] studied factors which influenced the online shopping habits of New Zealand consumers. The research focuses on how different types of online buyers perceived websites differently and the research's results showed that website design, website reliability, website customer service, and website privacy were the four dominant factors which affected consumer perceptions. There were different evaluations of website reliability and website design by buyers but the buyers had similar opinions regarding website privacy issues, indicating that privacy issues were important to these online buyers.

Pham et al. [16] studied the relationships between perceived value, convenience, and repurchase intention in the context of Vietnamese online shopping. The results indicated that the five dimensions of online shopping were access, transaction, search, evaluation, and convenience. The results also found that perceived value has an important role in online shopping intentions.

Yadav et al. [20] combined the TPB and TAM theories with an additional construct, perceived risk. The study was conducted with 210 young consumers in India. The results of this proposed conceptual framework successfully predicted consumers' intentions to adopt internet banking. The determinants of perceived usefulness, attitude, subjective norms, and perceived behavioral control significantly influenced consumer' intentions to adopt internet banking, whereas a non- significant, positive relationship was found between the domains of perceived risk and consumer intentions

\section{Materials and Methodology}

Conceptual Model: Prior research integrated the TAM and TPB models to predict customer intentions toward internet banking and online shopping ([13], [15], [20]). The results of these research efforts support the integration of the variables of the TAM and the TPB. Experiments showed that the accuracy and speed of the prediction model were greatly improved after optimized by the genetic algorithm ([19]), because in the Vietnamese emerging economy, other characteristics exist specific to this market as $m$ entioned above, especially the legal corridor and cash-using habits; therefore, our study integrated the TAM and the TPB to research customers' intentions to shop online by adding the reliability-law factor as a formative factor. Figure 1 describes the theoretical framework containing the 7 constructs.

The indicators and constructs of this research are presented in Appendix 1.

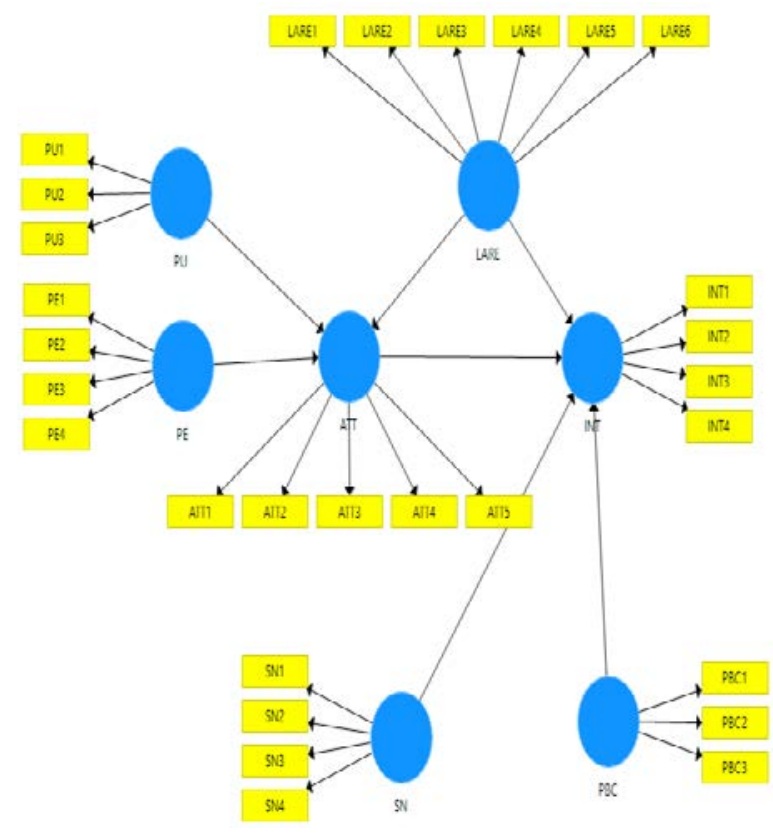

Fig.1. Theoretical framework.

Source: Compiled by the authors.

The thirteen hypotheses of study are presented as follows:

$\mathrm{H}_{1}$ : Perceived ease-of-use (PE) is positively related to perceived usefulness (PU) in online shopping use;

$\mathrm{H}_{2:}$ PE is positively related to attitude (ATT) in online shopping use;

$\mathrm{H}_{3}$ : PU is positively related to ATT in online shopping use; 
$\mathrm{H}_{4:}$ Law and reliability factor (LARE) is positively related to ATT in online shopping use;

$\mathrm{H}_{5}$ : LARE is positively related to behavioral intention (INT) in online shopping use;

$\mathrm{H}_{6:}$ ATT is positively related to INT in online shopping use;

$\mathrm{H}_{7}$ : Subjective norms (SN) are positively related to INT in online shopping use;

$\mathrm{H}_{8:}$ Perceived behavioral control (PBC) is positively related to INT in online shopping use;

$\mathrm{H}_{9:}$ PE indirectly affects INT via ATT;

$\mathrm{H}_{10}$ : $\mathrm{PU}$ indirectly affects INT via ATT;

$\mathrm{H}_{11}$ : LARE indirectly affects INT via ATT;

$\mathrm{H}_{12:}$ PE indirectly affects ATT via PU;

$\mathrm{H}_{13}$ : PE indirectly affects INT via PU and ATT.

\section{The Data:}

The convenience sample method was used in collecting data, because this method allowed the researchers to obtain responses in a co st-effective way ([14]).

Table 1. Descriptive statistics of samples

\begin{tabular}{|l|c|c|}
\hline \multicolumn{1}{|c|}{ Age Group } & Number & $\begin{array}{c}\text { Frequency } \\
(\%)\end{array}$ \\
\hline From 15 to 20 years old & 100 & \\
From 21 to 40 years old & 220 & 25 \\
Over 40 years old & 80 & 20 \\
& & \\
\hline Earnings per month & & \\
\hline Under US \$500 & 240 & 60 \\
From US \$500-1000 & 120 & 30 \\
Over US \$1000 & 40 & 10 \\
\hline & & \\
\hline No job & 20 & 5 \\
Student & 60 & 15 \\
Employed & 200 & 55 \\
Retired & 80 & 20 \\
Other & 20 & 5 \\
\hline Gender & 80 & \\
\hline Male & 320 & 80 \\
Female & & \\
\hline
\end{tabular}

The survey was implemented from March 2019 to August 2019 i n Da Nang City, Vietnam, with 420 respondents, of which there were 400 suitable samples for analysis.
A five-point Likert scale was used in the questionnaires to collect information from online shopping users. Table 1 presents detailed information regarding the 400 samples respondents as 80 percent of respondents ar e female and 10 percent of them get earning bigger than $\$ 1000$ per month.

\section{Problem Solution}

The study uses the Smart PLS 3.0 software to identify the relationships that exist between the constructs and the indicator variable ([17]) and implements $\mathrm{ab}$ ootstrap procedure to test the significance levels of coefficients ([6]). The research model includes seven reflective measurement constructs and analyzes the outer loading of the indicators and the average variance validity to test the convergent validity of the model. The outer loadings of all of the indicators were expected to be statistically significant and were required to be above 0.70 .

The measurement model has 29 indicators, but 5 indicators (LARE4, LARE5, LARE6, INT4, and ATT4) were eliminated because their outer loadings were smaller than 0.70 . The observed variables were reliable; therefore, 24 variables were used in the analysis (Table 2).

\subsection{Measurement Model}

According to Henseler et al. [12], $\mathrm{R}^{2}$ values of 0.25 , 0.5 , or 0.75 for endogenous latent variables could be described as w eak, moderate, or substantial, respectively. The $\mathrm{R}^{2}$ value of INT was 0.89 , indicating

that about $89 \%$ of the variance in INT was explained by the research model; this was a substantial level (Table 3). The $\mathrm{R}^{2}$ values of the endogenous latent variables are presented inside the blue ellipse in Figure 2.

Table 3. $\mathbf{R}^{2}$ values.
\begin{tabular}{|c|c|c|}
\hline & $\mathbf{R}^{2}$ & $\mathbf{R}^{2}$ Adjusted \\
\hline ATT & 0.715 & 0.713 \\
\hline INT & 0.895 & 0.894 \\
\hline PU & 0.582 & 0.581 \\
\hline
\end{tabular}
Source: Compiled by the authors.

\subsection{Composite Reliability}

Composite reliability (CR) was used to measure the internal consistency reliability based on the correlations of the observed indicator variables. Hair 
et al., [8] suggested a minimum threshold of 0.7 to be acceptable. In the model, all of the CR values were greater than 0.70 , indicating that the model had composite reliability.

Table 2. Outer Loading.

\begin{tabular}{|c|c|c|c|c|c|c|c|}
\hline & ATT & INT & LARE & PBC & PE & $\mathrm{PU}$ & SN \\
\hline ATT1 & 0.812 & & & & & & \\
\hline ATT2 & 0.780 & & & & & & \\
\hline ATT3 & 0.768 & & & & & & \\
\hline ATT5 & 0.767 & & & & & & \\
\hline INT1 & & 0.762 & & & & & \\
\hline INT2 & & 0.846 & & & & & \\
\hline INT3 & & 0.858 & & & & & \\
\hline LARE1 & & & 0.837 & & & & \\
\hline LARE2 & & & 0.829 & & & & \\
\hline LARE3 & & & 0.754 & & & & \\
\hline PBC1 & & & & 0.800 & & & \\
\hline $\mathrm{PBC} 2$ & & & & 0.804 & & & \\
\hline PBC3 & & & & 0.746 & & & \\
\hline PE1 & & & & & 0.853 & & \\
\hline PE2 & & & & & 0.848 & & \\
\hline PE3 & & & & & 0.788 & & \\
\hline PE4 & & & & & 0.773 & & \\
\hline PU1 & & & & & & 0.749 & \\
\hline PU2 & & & & & & 0.736 & \\
\hline PU3 & & & & & & 0.757 & \\
\hline SN1 & & & & & & & 0.763 \\
\hline SN2 & & & & & & & 0.778 \\
\hline SN3 & & & & & & & 0.722 \\
\hline SN4 & & & & & & & 0.750 \\
\hline
\end{tabular}

Source: Compiled by the authors.

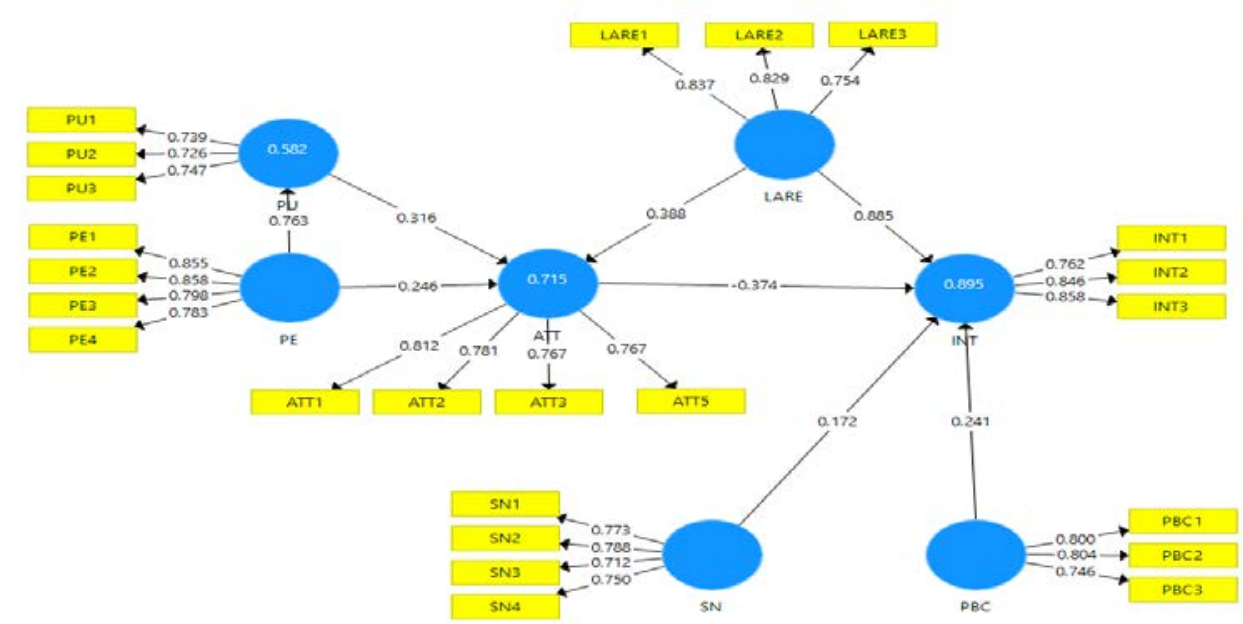

Fig. 2. The results of Partial least squares-structural equation modeling 


\subsection{Convergent Validity}

The average variance extracted (AVE) was used to measure the convergent validity of the construct. Hair et al, [9] suggested than an AVE value of 0.50 or greater was acceptable for the indicators. All seven of the reflective constructs used in this research model had AVE values greater than 0.50, therefore the research model was considered to have convergent validity (Table 4).

Table 4. Construct Reliability and Validity

\begin{tabular}{|l|c|c|}
\hline & $\begin{array}{c}\text { Composite } \\
\text { Reliability }\end{array}$ & $\begin{array}{c}\text { Average Variance } \\
\text { Extracted }\end{array}$ \\
\hline ATT & 0.853 & 0.621 \\
\hline INT & 0.863 & 0.667 \\
\hline LARE & 0.858 & 0.642 \\
\hline PBC & 0.837 & 0.624 \\
\hline PE & 0.884 & 0.689 \\
\hline PU & 0.781 & 0.544 \\
\hline SN & 0.842 & 0.572 \\
\hline
\end{tabular}

Source: Compiled by the authors

\subsection{Discriminant Validity}

Discriminant validity describes whether a construct is unique in the research model. In this study, the heterotrait monotrait ratio (HTMT) was used to measure the discriminant validity of the indicators. Henseler et al., [11] suggested a threshold value of 0.90 if the path model included constructs that were conceptually very similar. To derive a st atistical distribution of the HTMT, a procedure called bootstrapping was used. The lower and upper bounds of the confidence interval of HTMT for the relationship between ATT and INT were -0.444 and

0.312, respectively, and those for the relationship between LARE and ATT were 0.288 a nd 0.474, respectively. The HTMT values of all seven constructs in this study were smaller than 0.90; thus, the reflective measurement construct was considered to possess discriminant validity (Table 5)

\subsection{Evaluating Effect Size}

The $f^{2}$ effect size was used to evaluate whether the omitted constructs had a substantive impact on the endogenous constructs; the measurement of the $\mathrm{f}^{2}$ effect size is increasingly encouraged by journal editors and reviewers. An effect size value of less than 0.02 would indicate no effect ([4]). All of the constructs, i.e., LARE, ATT, SN, and PBC, had effects on the endogenous latent variable INT of greater than 0.02 ; therefore, the omitted constructs had impacts on the endogenous construct (Table 6).

\subsection{Hypothesis Testing}

The bootstrapping procedure was implemented to access the significance and relevance of the structural model relationships. Hair et al.,[8] stated that commonly-used critical values for two-tailed tests are 1.65 (significance level $=10 \%), 1.96$ (significance level $=5 \%$ ), and 2.57 (significance level $=1 \%$ ). The relationship between LARE and INT was accepted according to $\mathrm{H}_{5}(\mathrm{t}=30.576, \mathrm{p}<0.05)$. Consequently, the relationship between ATT and INT was accepted according to $\mathrm{H}_{6}(\mathrm{t}=11.340, \mathrm{p}<0.05)$, the relationship between $\mathrm{SN}$ and INT was accepted according to $\mathrm{H}_{7}(\mathrm{t}$ $=3.437, \mathrm{p}<0.05)$, and the relationship between PBC and INT was accepted according to $\mathrm{H}_{8}(\mathrm{t}=5.501, \mathrm{p}<$ $0.05)$. The results in Table 7 also depict the path coefficients of the respective constructs with their levels of significance. The eight hypotheses regarding the direct relationships between the constructs, i.e., $\mathrm{H}_{1}$,

$\mathrm{H}_{2}, \mathrm{H}_{3}, \mathrm{H}_{4}, \mathrm{H}_{5}, \mathrm{H}_{6}, \mathrm{H}_{7}$, and $\mathrm{H}_{8}$, were accepted (Table 7 and Figure 3 ).

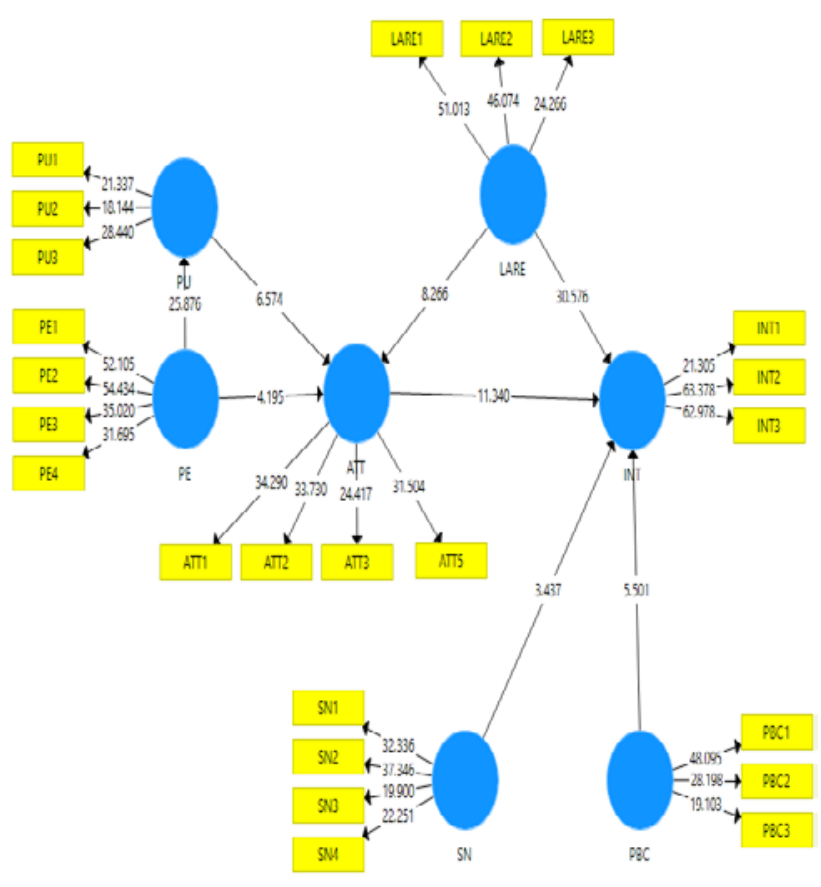

Fig. 3. Measurement Model. 
Table 5. Corrected confidence interval biases.

\begin{tabular}{|l|c|c|c|c|c|}
\hline & $\begin{array}{c}\text { Original Sample } \\
(\mathrm{O})\end{array}$ & $\begin{array}{c}\text { Sample Mean } \\
(\mathrm{M})\end{array}$ & Bias & $2.5 \%$ & $97.5 \%$ \\
\hline ATT -> INT & -0.374 & -0.372 & 0.002 & -0.444 & -0.312 \\
\hline LARE -> ATT & 0.388 & 0.389 & 0.001 & 0.288 & 0.474 \\
\hline LARE -> INT & 0.885 & 0.885 & 0.000 & 0.828 & 0.840 \\
\hline PBC -> INT & 0.241 & 0.239 & -0.002 & 0.152 & 0.328 \\
\hline PE -> ATT & 0.246 & 0.245 & -0.002 & 0.138 & 0.367 \\
\hline PE -> PU & & & & & 0.815 \\
\hline PU -> ATT & 0.763 & 0.762 & -0.001 & 0.699 & 0.411 \\
\hline SN -> INT & 0.316 & 0.316 & 0.000 & 0.219 & 0.274 \\
\hline
\end{tabular}

Source: Compiled by the authors.

Table 6. $\mathrm{f}^{2}$ values.

\begin{tabular}{|c|c|c|c|c|c|c|c|}
\hline & ATT & INT & LARE & PBC & PE & PU & SN \\
\hline PE & 0.076 & & & & & 1.392 & \\
\hline PU & 0.137 & & & & & & \\
\hline LARE & 0.268 & 2.232 & & & & & \\
\hline ATT & & 0.301 & & & & & \\
\hline INT & & & & & & & \\
\hline PBC & & 0.080 & & & & & \\
\hline SN & & 0.038 & & & & & \\
\hline
\end{tabular}

Source: Compiled by the authors. 
Table 7. Path Coefficients.

\begin{tabular}{|l|c|c|c|c|c|l|}
\hline & $\begin{array}{c}\text { Original } \\
\text { Sample } \\
(\mathrm{O})\end{array}$ & $\begin{array}{c}\text { Sample } \\
\text { Mean (M) }\end{array}$ & $\begin{array}{c}\text { Standard } \\
\text { Deviation } \\
(\text { STDEV) }\end{array}$ & $\begin{array}{c}\text { T Statistics } \\
(|\mathrm{O} / \mathrm{STDEV}|)\end{array}$ & P Values & $\begin{array}{c}\text { Is the hypothesis } \\
\text { valid? }\end{array}$ \\
\hline PE -> PU & 0.763 & 0.762 & 0.029 & 25.876 & 0.000 & $\mathrm{H}_{1}$ is accepted \\
\hline PE -> ATT & 0.246 & 0.245 & 0.059 & 4.195 & 0.000 & $\mathrm{H}_{2}$ is accepted \\
\hline PU -> ATT & 0.316 & 0.316 & 0.048 & 6.574 & 0.000 & $\mathrm{H}_{3}$ is accepted \\
\hline LARE -> ATT & 0.388 & 0.389 & 0.047 & 8.266 & 0.000 & $\mathrm{H}_{4}$ is accepted \\
\hline LARE -> INT & 0.885 & 0.885 & 0.029 & 30.576 & 0.000 & $\mathrm{H}_{5}$ is accepted \\
\hline ATT -> INT & -0.374 & -0.372 & 0.033 & 11.340 & 0.000 & $\mathrm{H}_{6}$ is accepted \\
\hline SN -> INT & 0.172 & 0.172 & 0.050 & 3.437 & 0.001 & $\mathrm{H}_{7}$ is accepted \\
\hline PBC -> INT & 0.241 & 0.239 & 0.044 & 5.501 & 0.000 & $\mathrm{H}_{8}$ is accepted \\
\hline
\end{tabular}

Source: Compiled by the authors.

Table 8. Total Indirect Effects.

\begin{tabular}{|c|c|c|c|c|c|}
\hline & $\begin{array}{c}\text { Original } \\
\text { Sample }(\mathrm{O})\end{array}$ & $\begin{array}{c}\text { Sample } \\
\text { Mean (M) }\end{array}$ & $\begin{array}{l}\text { Standard } \\
\text { Deviation } \\
\text { (STDEV) }\end{array}$ & $\begin{array}{c}\text { T Statistics } \\
(|\mathrm{O} / \mathrm{STDEV}|)\end{array}$ & P Values \\
\hline \multicolumn{6}{|l|}{ ATT $->$ INT } \\
\hline \multicolumn{6}{|l|}{ LARE -> ATT } \\
\hline LARE -> INT & -0.145 & -0.145 & 0.022 & 6.662 & 0.000 \\
\hline \multicolumn{6}{|l|}{ PBC -> INT } \\
\hline PE -> ATT & 0.241 & 0.241 & 0.039 & 6.137 & 0.000 \\
\hline PE -> INT & -0.182 & -0.181 & 0.025 & 7.193 & 0.000 \\
\hline \multicolumn{6}{|l|}{$\mathbf{P E}->\mathbf{P U}$} \\
\hline \multicolumn{6}{|l|}{ PU -> ATT } \\
\hline PU -> INT & -0.118 & -0.118 & 0.021 & 5.568 & 0.000 \\
\hline SN -> INT & & & & & \\
\hline
\end{tabular}

Source: Compiled by the authors.

Table 8 indicates the total indirect effects of the constructs in the model.

The hypotheses $\mathrm{H}_{9}, \mathrm{H}_{10}$, and $\mathrm{H}_{11}$ were evaluated via specific indirect effects (Table 9). In Table 9, the specific indirect effects between LARE and INT, between PE and INT, and between PU and INT were considered to be statistically significant (p-value < 0.05). Therefore, the hypotheses $\mathrm{H}_{9}, \mathrm{H}_{10}, \mathrm{H}_{11}, \mathrm{H}_{12}$, and $\mathrm{H}_{13}$ accepted 
Table 9. Specific Indirect Effects.

\begin{tabular}{|l|c|c|c|c|c|c|}
\hline & $\begin{array}{c}\text { Original } \\
\text { Sample } \\
(\mathrm{O})\end{array}$ & $\begin{array}{c}\text { Sample } \\
\text { Mean } \\
(\mathrm{M})\end{array}$ & $\begin{array}{c}\text { Standard } \\
\text { Deviation } \\
(\mathrm{STDEV})\end{array}$ & $\begin{array}{c}\text { T Statistics } \\
(|\mathrm{O} / \mathrm{STDEV}|)\end{array}$ & P Values & $\begin{array}{c}\text { Is the } \\
\text { hypothesis } \\
\text { valid? }\end{array}$ \\
\hline PE -> ATT -> INT & -0.092 & -0.091 & 0.023 & 3.948 & $\mathbf{0 . 0 0 0}$ & $\mathrm{H}_{9}$ is accepted \\
\hline PU -> ATT -> INT & -0.118 & -0.118 & 0.021 & 5.568 & 0.000 & $\mathrm{H}_{10}$ is accepted \\
\hline $\begin{array}{l}\text { LARE -> ATT -> } \\
\text { INT }\end{array}$ & -0.145 & -0.145 & 0.022 & 6.662 & $\mathbf{0 . 0 0 0}$ & $\mathrm{H}_{11}$ is accepted \\
\hline PE -> PU -> ATT & 0.241 & 0.241 & 0.039 & 6.137 & 0.000 & $\mathrm{H}_{12}$ is accepted \\
\hline $\begin{array}{l}\text { PE -> PU -> ATT -> } \\
\text { INT }\end{array}$ & -0.090 & -0.090 & 0.018 & 5.103 & 0.000 & $\mathrm{H}_{13}$ is accepted \\
\hline
\end{tabular}

Source: Compiled by the authors.

\subsection{Mediation Analysis}

When a third variable intervenes between two other related constructs, this relationship is described as mediation ([9], where a mediator variable governs the nature of the relationship between two constructs. From Figure 3 and Table 9, it can be seen that attitude (ATT) served as mediator variable in the relationship between LARE (reliability-law) and INT (intention to use online shopping). ATT also had the role of the mediator variable in the relationship between PE and INT, and between PU and INT.

\subsection{Importance Performance Matrix Analysis (IPMA)}

IPMA represents a valuable tool used to extend the results obtained from the standard PLS-SEM estimations by contrasting the total effects of the latent variables on target variables with their latent variable scores. IPMA compared the structural model's total effects on a specific target construct (intention to shop online-INT) with the average latent variable scores of this construct's predecessors (attitude, reliability-law, subjective norms, and perceived behavioral control). The total effects represented the predecessor constructs' importance in shaping INT, while their average latent variable scores represented their performance. The goal of using IPMA is to represent a $p$ otential area for improvement that may be of interest. We created an importance-performance map to illustrate this concept, as shown in Figure 4.
+ The $\mathrm{x}$-axis represents the (unstandardized) total effects of the attitude, subjective norms, perceived behavioral control, law, and reliability domains on the target construct (intention to shop online).

+ The y-axis depicts the average rescaled (unstandardized) latent variable scores of the attitude, subjective norms, perceived behavioral control, law, and reliability domains.

Figure 4 shows that the reliability-law and perceived behavior control domains were the two most important constructs regarding the determination of the behavioral intentions of online shopping consumers; this was due to their greater importance values compared to other latent variables. Thus, authorities and companies should focus on improving their performances in the reliability-law domain and their consumers' perceived behavior control. 


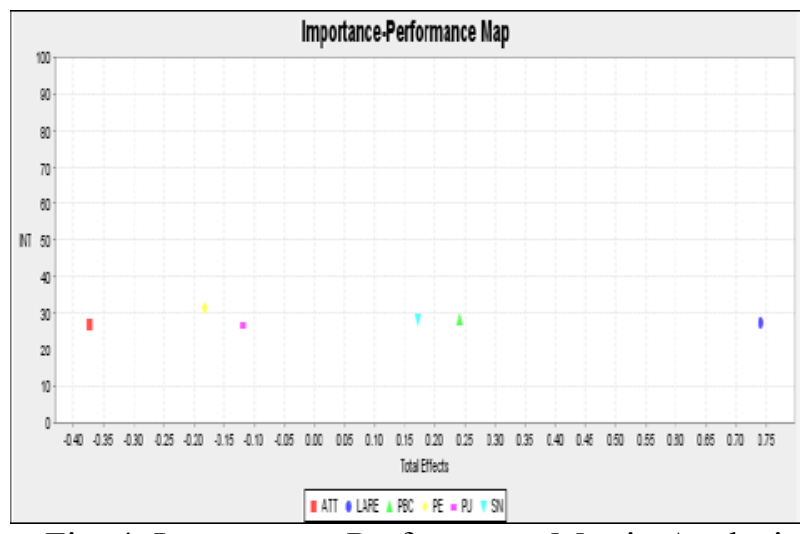

Fig. 4. Importance-Performance Matrix Analysis

\section{Conclusion}

This study integrated the TAM and TPB models to research customers' intentions to shop online in by adding the reliability-law construct as a formative factor. The results demonstrated that the reliabilitylaw factor greatly affected online shoppers' behavioral intentions. Perceived behavioral control, subjective norms, and attitudes also influenced customers' intentions to shop online. The more customers thought that they could control and seek information regarding the quality, price, and delivery manner of online products, the more they intended to buy the online products.

The results indicated that the proposed model was applicable to measure consumers' intentions to shop online in Vietnam. The findings in the paper also showed that the reliability-law factor had a significant influence on o nline shopping behavior. Together with

the other factors described in the model, the reliability-law factor improved the predictive utility of the proposed model-and consequently, actual predictions - to determine consumers' intentions to shop online.

The study integrates TAM and TPB in that it added the reliability- law factor as a formative factor in order to study customers' behavior in online shopping. In the Vietnam emerging economy with the lack of a legal corridor, activities about online shopping met many obstacles and difficulties which have been restricted in developing Vietnam's online shopping market. Finally, it $\mathrm{w}$ as concluded in this research that extending the TPB and TAM with a reliability-law factor was useful to identify online shopping behaviors and the intentions of Vietnamese consumers ass it could use in researching about online shopping in developing countries

\section{Recommendation}

To sustainably develop Vietnam's online shopping market over the coming years, this study proposes some recommendations, which are described as follows:

- The Vietnamese government needs to improve the Vietnam legal corridor for e-commerce in regard to online shopping. The laws concerning e-commerce must protect customers and full regulations must exist to prevent and control commercial fraud and origin risks. The relevant state offices must strictly control and inspect for implementation, which is a necessary

aspect in order to strengthen the management of the online shopping market

-Preventing hacker violate systems, steal customer information by searching for passwords, then make credit transfers. Furthermore, cybersecurity is vital to nurture consumer trust in the digital economy. Unfortunately, according to Kaspersky Lab, Vietnam was the country most susceptible to Internet Chess Server attacks and the third most prone to cyber threats in 2018. Therefore, the State Bank of Vietnam should coordinate with the Ministries to take measures to ensure the security of information and prevent crime, as well as the protection of customers' interests and the reduction in risks and losses for the banks themselves.

-To increase the purchase intentions of customers, company websites should include: (1) Building a full view of the products and a f eedback system so customers can give valuable comments, which would help to increase customer confidence when online shopping; (2) Improving a website with a u serfriendly interface designed to allow customers to easily compare products to help them to seek out the products that best meet their needs; and (3) investing machines to increase the speed of online access and transactions.

-Informations about products must be provided to customer so customers can accurately evaluate the products they want to purchase. Customers should be received accurate and full details about products, about the place and time of delivery so that they are involved when receiving their goods. The goods should be packaged carefully to avoid damage 
during transport. In Vietnam, traditional payment methods of cash or cash-on-delivery are still common, therefore suppliers must clearly introduce the method of payment upon de livery. All of these factors are expected to increase customers' trust, thereby increasing their online shopping behavior.

-The privacy and protection of consumers' personal information is an important problem. Consumers want to be able to control who has access to their personal information. Cybersecurity and Vietnam should also upgrade its online network so that consumers can access high-speed internet; the implementation of educational initiatives to raise IT literacy are crucial. The government should encourage consumers to participate more actively in the digital economy and offer discounts for cashless payments. . Korea succeeded in this regard, with the country pushing the rate of people using cashless payment to $80 \%$ in 2017. personal data administration should be enhanced via specific and effective policies. Companies that want to collect, extract, or analyze consumer data in Vietnam must comply with local regulations regarding data protection and illegal content removal. Promotion of propaganda to enterprises and citizens regarding the usefulness and ease of online shopping will encourage online shopping trade.

\section{Limitations}

This study has some limitations. Vietnam legal corridor for e-commerce is still lack, online shopping in Vietnam was in spontaneous development by enterprises without close legislative control, which caused risks for online consumers. Future research should involve the collection of more data from other customers in many locations throughout Vietnam.

Notes:

${ }^{(1)}$ Economy SEA 2018. Google-Temasek Report 2018.

Available at: https://www.cnbc.com/2018/11/19/google-temasek-report-mobile-internet-is-driving-sea-interneteconomy.html

(2) Viet Nam Internet Network Information Center. Report On Viet Nam Internet Resource 2018.

Available at: https://vnnic.vn/en/report-on-vietnam-internet-resources?lang=en

(3) The E- Commerce Law of Vietnam (2005). Decree 52/2013/ND-CP on May 16, 2013 and Decree 722013/NDCP on July 15, 2013 on the management and supply of Internet and online information services.

References:

[1]Ajzen, I. (1985)., From intentions to action: A theory of planned behavior. In J. K. Beckman (Ed.), Action control: From cognitions to behaviors (pp. 11-39). New York: Springer.

[2]Ajzen, I. (1991). The theory of planned behavior. Organizational Behavior and Human Decision Processes. Vol.50, pp. 179211.

[3]Alsamydai M.J. (2014). Adaptation of the TAM to the use of mobile banking services. International Review of Management and Business Research, Vol. 3, No 4, pp. 2016 2028.

[4]Cohen J. (1988). Statistical power analysis for the behavioral sciences (2nd ed.).Hillside Mahwah, NJ: Lawrence Erlbaum.

[5]Davis F.D. (1989). Perceived usefulness, perceived ease of use and user acceptance of information technology. MIS Quarterly, Vol. 13, No 3, pp. 319-340.
[6]Davison A.C. and Hinkey D.V. (1997). Bootstrap methods and their application. Cambridge, UK: Cambridge University Press.

[7]Fishbein M. and Ajzen I. (1975). Belief, Attitude, Intention and Behavior: An introduction to theory and research. Addision - Wesley, Reading, MA.

[8]Hair, J.F., Anderson, R.E., Tatham, R.L., \& Black, W.C. (2005). Multivariate Data Analysis (6 ed.). Upper Saddle River, NJ: Prentice Hall.

[9]Hair J.F., Hult G.T., Ringle C.M. \& Sarstedt M. (2017). A primer on partial least squares structural equation modeling (2nd ed.), Thousand Oaks, CA: SAGE Publications.

[10]Hair J.F., Sarstedt M., Hopkins L. \& Kuppelwieser G.V (2014). Partial least squares structural equation modeling (PLS-SEM): An emerging tool in business research. European Business Review, Vol 26, No 2, pp. 106-121. 
[11]Henseler J., Ringle C.M.\& Sarstedt M.(2015). A new criterion for accessing discriminant validity in variance - based structural equation modelling. Academy of Marketing Science Journal, Vol. 43, No 1, pp. $115-127$.

[12]Henseler J., Ringle C.M. \& Sinkovics R.R. (2009). The use of partial least squares path modeling in international marketing. Advances in International Marketing, Vol. 20, pp.277-320.

[13]Lee S. H., and Ngoc H.T.B., (2010). Investigating the on-line shopping intentions of Vietnamese student: an extension of the theory of planned behavior. World Transactions on Engineering and Technology Education, Vol. 8, No 4, pp. 471-476.

[14]Martins C., Oliveira T. \& Popovie A. (2014). Understanding the Internet banking adoption: A unified theory of acceptance and use of technology and perceived risk application. International Journal of Information Management, Vol 34, No 1, pp. 1-13.

[15]Nasri, W. and Charfeddine, L. (2012). Factors affecting the adoption of internet banking in Tunisia: an integration theory of acceptance model and theory of planned behavior. The Journal of High Technology Management Research, Vol. 23 No. 1, pp. 1-14.

[16]Pham Q. T., Tran X.P., Misra S., Maskeliunas R., and Damasevicius R., (2018).Relationship
Between Convenience, Perceived Value, and Repurchase Intention in Online Shopping in Vietnam. Sustainability, Vol.18, No 156, pp. 0114.

[17]Sarstedt M., Ringle C.M., Hair J.F. (2017) Partial Least Squares Structural Equation Modeling. Handbook of Market Research (eds. C. Homburg, M. Klarmann, A. Vomberg), Heidelberg; New York; Dordrecht; London: Springer (print version forthcoming). DOI: 10.1007/978-3-319-05542-8_15-1. Available at: http://www.researchgate.net/ publication/319669432, accessed 02.05.2018.

[18]Shergill, G. S. and Chen, Z., (2005). Web Based shopping: Consumers'Attitudes Towards Online Shopping In New Zealand. Journal of Electronic Commerce Research, Vol. 6, No. 2, pp. 79 -94.

[19] Tingting Ye (2018). Research on the risk crisis prediction of enterprise finance by generic algorithm. International Journal circuits, systems and signal processing, Vol. 12, pp.319 $-324$.

[20]Yadav, R., Chauhan,V. and Pathak, G. (2015). Intention to adopt internet banking in an emerging economy: a $\mathrm{p}$ erspective of Indian youth. International Journal of Bank Marketing, Vol. 33, No 4, pp. 530 - 544.

\section{Appendix 1: Questionnaires}

Please answer the questions by ticking the appropriate answer.

1-Strongly disagree; 2-Disagree; 3-Neutral; 4-Agree; 5-Strongly agree.

\begin{tabular}{|c|c|c|c|c|c|c|}
\hline & & 1 & 2 & 3 & 4 & 5 \\
\hline \multicolumn{7}{|c|}{ Online shopping behavior intention } \\
\hline INT1 & I will keep using online shopping in the future. & & & & & \\
\hline INT2 & $\begin{array}{l}\text { Using online shopping rather than traditional shopping for } \\
\text { purchasing products in the future. }\end{array}$ & & & & & \\
\hline INT3 & I will introduce other persons to use online shopping. & & & & & \\
\hline INT4 & $\begin{array}{l}\text { In the coming years, I have plans to use online shopping } \\
\text { regularly. }\end{array}$ & & & & & \\
\hline \multicolumn{7}{|c|}{ Reliability-Law } \\
\hline LARE1 & $\begin{array}{l}\text { The Vietnam legal corridor about e-commerce is lacking and } \\
\text { inadequate. }\end{array}$ & & & & & \\
\hline LARE2 & $\begin{array}{l}\text { Shopping online users have difficulties in distinguishing } \\
\text { between counterfeit and known-origin goods }\end{array}$ & & & & & \\
\hline
\end{tabular}




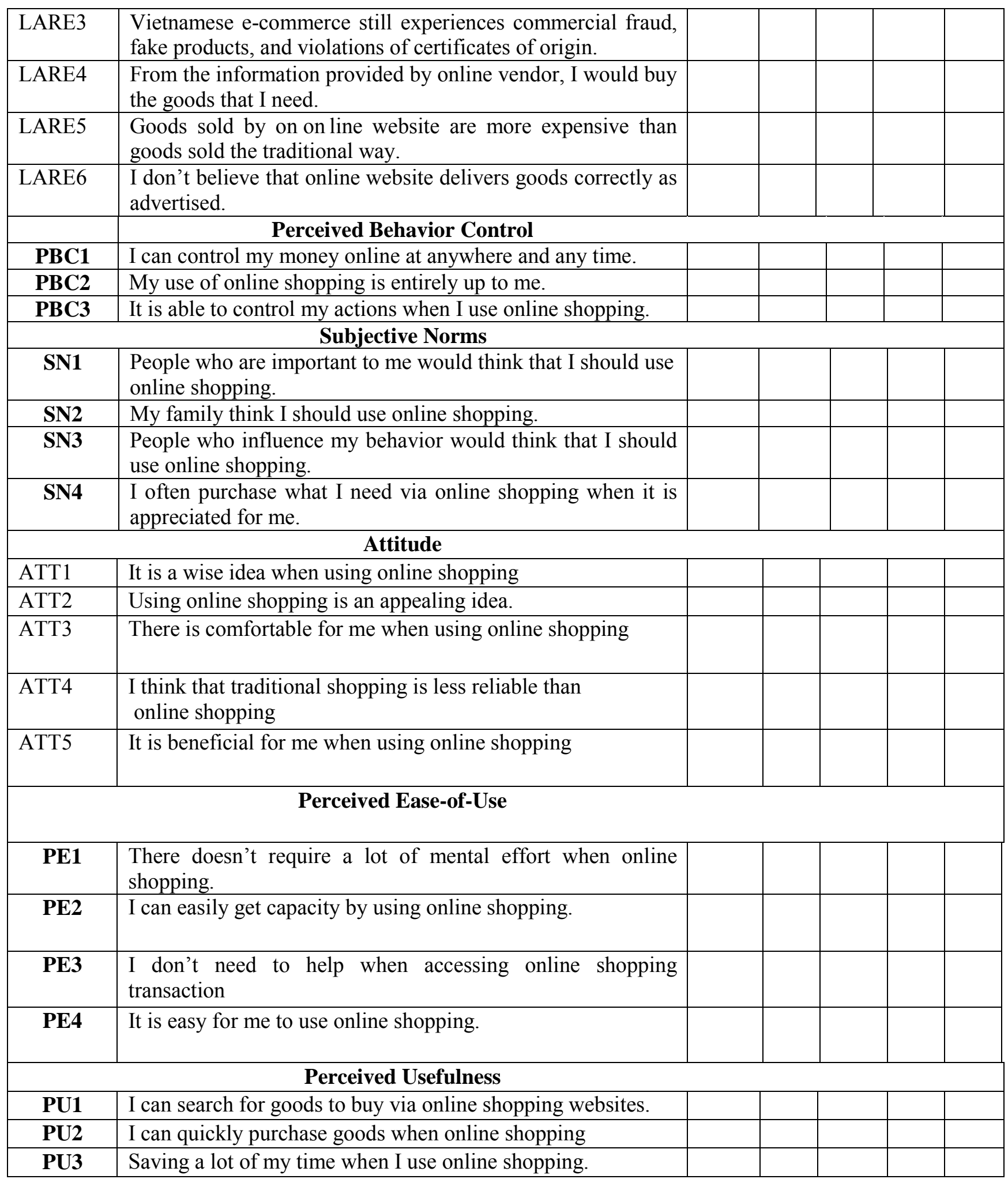

